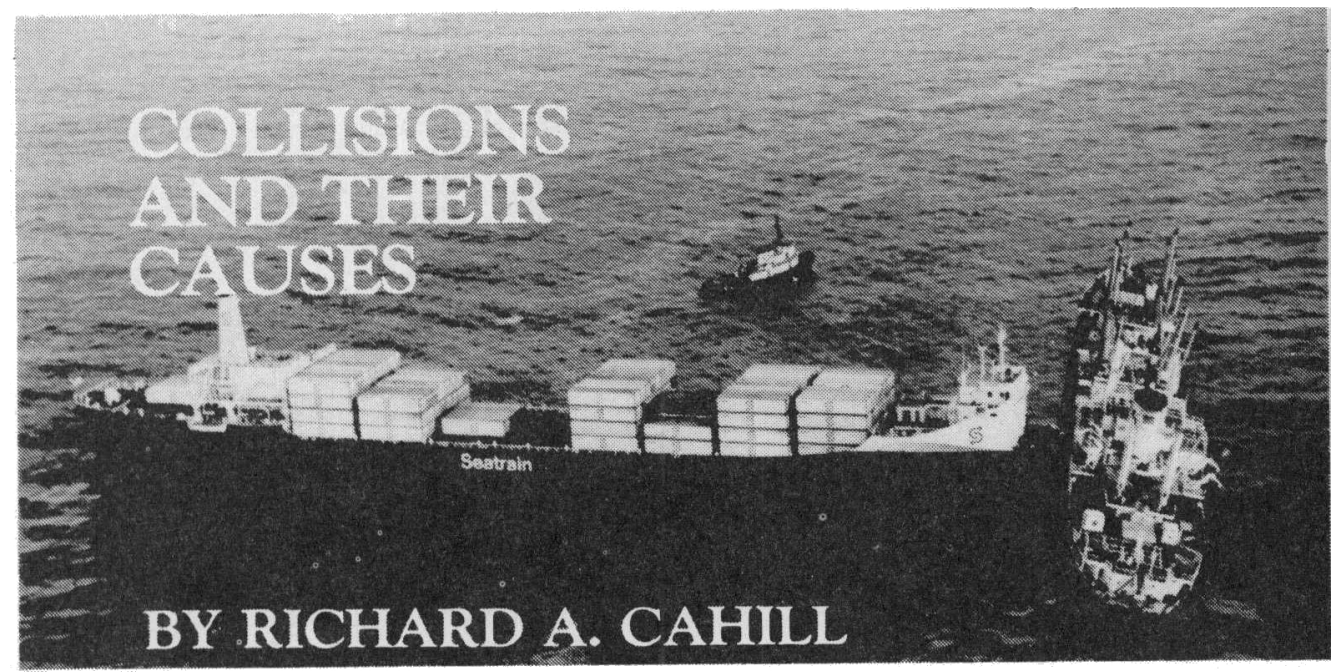

A practical book for the professional mariner, written by a serving shipmaster, this volume analyses a large number of collisions that have occurred, some well known and others less so, but each proving an important lesson. The accounts are filled with instances where basic principles and practices of seamen have been flouted or ignored, more often than not by seamen who knew, or should have known better, where careers were ruined and lives lost unnecessarily for the lack of thought or learning.

\title{
Contents include:
}

- Restricted visibility

- Forestalling close quarters

- The role of VHF and harbour radio

- Close quarters in clear weather

- In extremis situations
- Fine crossing and overtaking situations

- The hazards of close overtaking

- Meeting in narrow channels

- Collisions at anchor

- Keeping a proper look-out

\section{The Author}

Richard A. Cahill, who most recently has been in command of large American flag container-ships, graduated from the U.S. Merchant Marine Academy, Kings Point, in 1943. He has served afloat as a licensed deck officer since that time, being promoted to Master in 1961. A Fellow of the Royal Institute of Navigation, he is a past Member of its Technical Committee and currently a member of Council. He is also a Fellow of the Nautical Institute. He holds a Master's Degree in Business Administration from New York University and has served as a Visiting Professor in Nautical Science at the U.S. Merchant Marine Academy.

Price U.K. $£ 12.00$

Other Countries $f 13.00$ or U.S. $\$ 24.00$

Available from The Royal Institute of Navigation or direct from Fairplay Publications at the address below.

\section{PLEASE RETURN TO: FAIRPLAY PUBLICATIONS} 52/54 Southwark Street, London, SE1 1UJ

PAYMENT SHOULD ACCOMPANY ALL ORDERS PLEASE

\section{ORDER FORM}

Please send copy(ies) of:

\section{COLLISIONS AND THEIR CAUSES}

I enclose cheque
Name

\section{Address}

Bank Account Midland Bank, 5 Threadneedle St. London EC2R 8BD. Account No. 71026143

Reg. No. 338580 


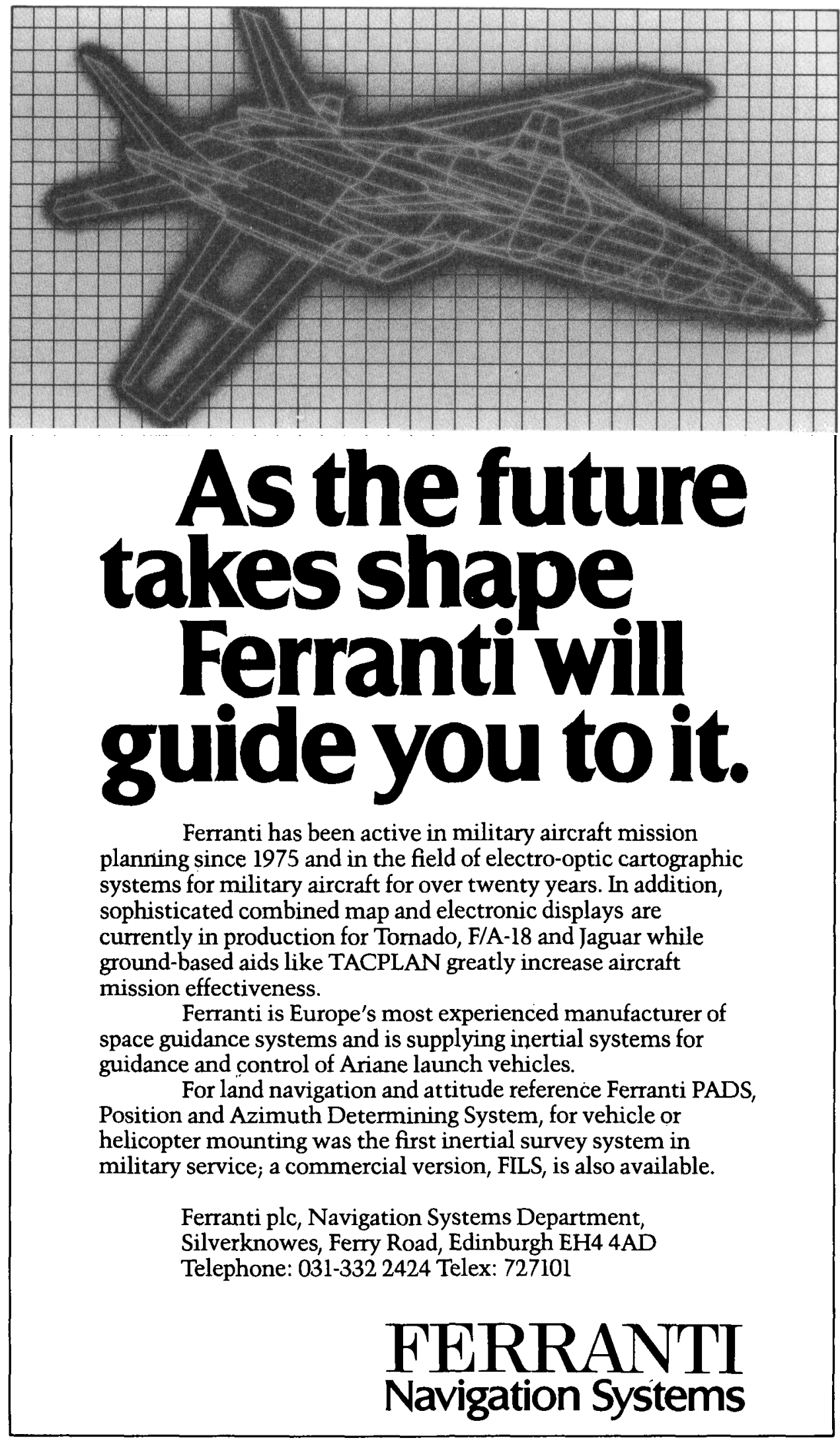




\section{THE INTERNATIONAL HYDROGRAPHIC REVIEW}

Half-yearly, 160 pages (approx.) $18 \times 27 \mathrm{~cm}$. Price 90 French francs* Yearly subscription 160 French francs*

Among the papers of interest in the January 1983 issue are:

- The first decade of GLORIA (A. S. LAUGHTON)

- The role of the sea and the seafarers in early geodesy (I. K. FISCHER)

- On the predictability of currents (G. GodiN)

PUBLISHED BY THE

INTERNATIONAL HYDROGRAPHIC BUREAU

7, av. President J. F. Kennedy,

B.P. 345 - MC 98000 MONACO

The Bureau also publishes monthly

\section{THE INTERNATIONAL HYDROGRAPHIC BULLETIN}

A bilingual journal - English and French - giving news of hydrographic activities worldwide. Lists in detail charts published by Member States of the International Hydrographic Organization, and contains a selective bibliography of recent works in the fields of hydrography, descriptive oceanography, navigation, cartography, etc.

Approx. 30 pages, $21 \times 30 \mathrm{~cm}, 10.50$ French francs per copy* Yearly subscription: 105 French francs*

* Postage extra 


\title{
THE JOURNAL OF NAVIGATION
}

\author{
Volume 36
}

1983

PUBLISHED UNDER THE AUTHORITY OE THE COUNCIL EDITED BY $M$. W. RICHEY

THE ROYAL INSTITUTE OF NAVIGATION AT THE ROYAL GEOGRAPHICAL SOCIETY

I KENSINGTON GORE, LONDON SW, $2 \mathrm{AT}$ 


\title{
THE ROYAL INSTITUTE OF NAVIGATION
}

\author{
PATRON
}

H.R.H. THE PRINCE PHILIP DUKE OF EDINBURGH, KG, KT, OM

\section{OFFICERS AND COUNCIL $1982-83$}

PRESIDENT

Captain B. J. Calvert

VICE-PRESIDENTS

Rear-Admiral D. W. Haslam, CB, OBE

D. M. Page

HONORARY TREASURER

G. E. Beck

CHAIRMAN OF THE TECHNICAL COMMITTEE

Dr J. F. Kemp

CHAIRMAN OF THE MEMBERSHIP AND FELLOWSHIP COMMITTEE

M. G. Pearson

J. H. Beattic

Wing Commander D. W. Broughton, MBE, RAF

Captain R. A. Cahill

Wing Commander E. E. Eatwell, RAF

Commander A. E. Fanning, MBE, DSC, RN (ret)
Other Members of Council

Captain L. W. Fifield

Lieutenant Commander H. D. Howse, $\mathrm{MBE}, \mathrm{DSC}, \mathrm{RN}$

Commander J. Paton, kN (ret)

Commander P. Le Pla, RN

Commander M. R. H. Llewellyn, RD, RNR (ret)

\section{DIRECTOR}

Rear Admiral R. M. Burgoyne, $\mathrm{CB}$ 


\section{CONTENTS}

THE PROVINCE OF THE INSTITUTE. M. W. RICHEY . • . . . I

HUMAN ASPECTS OF INTEGRATED NAVIGATION IN THE AIR. V.D. HOPKIN

AIRCRAFT SEPARATION ASSURANCE: SYSTEMS DESIGN. P. BROOKER $\dot{\bullet}$ THE ROLE OF ADVANCED NAVIGATION IN FUTURE AIR TRAFFIC MANAGEMENT. R. C. RAWUINGS

POSSIBLE IMPROVEMENTS IN METEOROLOGY FOR AIRCRAFT NAVIGation. M. Bisiaux, M. E. Cox, D. A. Forrester and J. T. Storey SELF-ADAPTIVE FILTERS FOR THE INTEGRATION OF NAVIGATION DATA. J. P. AbBott and C. R. Gent .

THE IMPACT OF FILTERING ON SEA AND AIR OPERATIONS. M. G. PEARSON

THE 'MANAV' INTEGRATED NAVIGATION SYSTEM. I. C. MiLlar and R. F. HANSFORD .

THE ADMIRALTY CHART - VI - HYDROGRAPHIC DEPARTMENT: CHARTING FOR MODERN NEEDS. D. W. HASLAM; RECENT SURVEYS. R. DE F. BROWNE; CHANGES IN ADMIRALTY CHART SPECIFICATION. G. A. MAGEE; THE USE AND MISUSE OF CHARTS. R. O. Morris; THE ENGLISH CHANNEL PASSAGE PLANNING GUIDE. H. R. W. HalliWell; ADMIRALTY SAILING DIRECTIONS. J. S. N. Pryor .

THE WORK OF THE INTERNATIONAL HYDROGRAPHIC ORGANISATION. G. S. RITCHIE

THE STILL UNDISCOVERED ORIGIN OF PORTOLAN CHARTS. H. C. FREIESLEBEN

THE ESTIMATION OF THE MEAN SIZE OF SHIP DOMAINS. W. G. P. LAMB ROTATIONS IN NAVIGATION. E. W. ANDERSON

A NEW CONCEPT FOR VERTICAL SEPARATION (Forum). A. BLOM-BAKKE NAVIGATION SAFETY IN EUROPEAN WATERS. Aline De Bièvre . . DESIGNING A NORTH SEA SHIPPING ROUTE. J. A. VAN RieT, R. TRESFon, R. A. W. Pollen and A. P. Valstar

THE CHANNEL NAVIGATION INFORMATION SERVICE. R. K. EMDEN THE PREDICTION OF SAFETY MARGINS AT SEA. J. HAGART
MEASUREMENTS USED IN EXPERIMENTS TO EVALUATE THE PERFORMANCE OF WATCH OFFICERS. J. F. CoOK aNd C. M. CrawshaW . 220 A RETURN TO THE SUMNER LINE? D. H. SAdLER . . . . . 231 A BRIEF HISTORICAL SURVEY OF BRITISH NAVIGATIONAL MANUALS. C. H. COTTER

A BRIEF HISTORY OF SAILING DIRECTIONS. C. H. COTTER . . . . A THEORETICAL FRAMEWORK FOR ANALYSIS OF LATERAL POSITION ERRORS IN VOR JET-ROUTE SYSTEMS. D. A. HSU . . . . . ON THE USE OF HEIGHT RULES IN OFF-ROUTE AIRSPACE. R. L. FORD . COMPUTER MODEL OF A COLLISION-AVOIDANCE SYSTEM FOR AIR TRAFFIC CONTROL. S. MORLEIGH

SOME ASPECTS OF MILITARY NAVIGATION: THE ARMY AIR CORPS.

R. Eccles. THE USE OF INERTIAL TECHNIQUES. A. E. Elias and G. B. HAMILTON .

THE CALCULATION OF LOXODROMIC DISTANCES (Forum). A. SPOSITo . THE ANDERSON THEOREM (Forum). E. W. ANDERSON MANOEUVRING TIMES, DOMAINS AND ARENAS (Forum). B. A. Colley, R. G. Curtis and C. T. STOckel. AN INQUIRY INTO SIMULATOR TRAINING (ForUm). G. M. VEENMAN AND W. VERHAGE 
NAVSTAR GPS FOR NAVIGATION: PRINCIPLES AND PRESENT STATUS.

G. E. CooK; GPS FOR AVIATION. S. RATCLIFFE; GPS FOR MARINE NAVIGATION. R. MAYBOURN . . . . . . . . . INTEGRATED NAVIGATION SYSTEMS FOR AIRCRAFT. R. F. STOKES AND S. G. SMITH .

NEW DISPLAY SYSTEMS FOR THE NEXT GENERATION OF AIRCRAFT. MOURCES OF LATITUDE ERROR IN ENGLISH SIXTEENTH CENTURY NAVIGATION. G. M. FORTY . A NEW RADAR DISPLAY AND

PLOT TECHNIQUE. A. S. LENART

COLLISION AVOIDANCE FROM THE SHORE. T. DEGRÉ AND X. LEFÈVRE : QUANTITATIVE MEASUREMENTS OF NAVIGATIONAL SAFETY. E. M.

Goodwin, W. G. P. Lamb and J. F. Kemp • . . . . . . 418

MARINE TRAFFIC BEHAVIOUR IN RESTRICTED WATERS. T. G. ColdWELL $43^{\circ}$

TRAFFIC CONTROL IN SEPARATION SCHEMES. W. FILIPOWICZ • . 445

DEFINING THE CLOSE-QUARTERS SITUATION AT SEA. H. HILGER • • $\quad 454$

THE EFFECTIVENESS OF SHIP ROUTING OFF NORTH WEST EUROPE.

А. N. СосксRоFт . . . . . . . . . . . 462

NAUTICAL CHART STANDARDIZATION. D. NEWSON : . . . 468

SHIP-BASED WEATHER ROUTING USING DYNAMICAL METEOROLOGY.

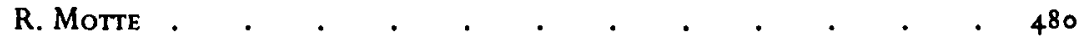

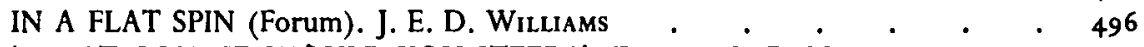

'WHAT COURSE SHOULD YOU STEER?' (Forum). L. R. MUIR . . . 500

USE OF INSHORE TRAFFIC ZONES (Record). A.N.C. . . . . . 505 


\section{THE ROYAL INSTITUTE OF NAVIGATION}

THE OBJECT of the Institute is to unite in one body those who are con1 cerned with or who are interested in the science and art of navigation. Memberahip is not restricted to those who hold professional qualifications, but is open to others who wish to further the aims of the Institute.

By coordinating the knowledge and achievements of marine and air navigators, scientists and those associated with the development and production of navigational equipment, the work of the Institute is directed towards raising the standard of navigation. In the field of education it is the aim of the Institute to bring practical navigators into contact with teachers and research workers to increase a common appreciation of the issues involved. It is an object of the Institute to encourage research in equipment and methods; through its publications it gives a wide circulation to original work on navigation so that new developments and suggestions can be appreciated by those most directly concerned with them.

The activities of the Institute include the holding of monthly meetings to discuss specific problems, the publication of a Journal and of other works concerned with different aspects of navigation, and such other activities as the Council may deem necessary to promote knowledge in navigation and its associated sciences.

The Journal of Navigation is issued free to all Members and contains a full account of the Institute's proceedings. It prints the papers which are presented at meetings, together with their ensuing discussion, and other original papers contributing to the science of navigation. It also contains a record of current navigational work, reviews of important books, and general papers of interest to navigators and those with similar interests.

The work of the Institute is coordinated with that of similar societies abroad, whose proceedings are available to members.

Membership. There are five classes of membership of the Institute:

(1) HONORARY MEMBERs, who shall be distinguished persons upon whom the Council may see fit to confer an honorary distinction.

(2) Fellows, who shall be members, of at least three years' standing who, in the opinion of the Council, have made a contribution of value to navigation.

(3) MEMBERs, who shall be persons over twenty-one years of age who can satisfy the Council of their interest in navigation.

(4) STUDENT MEMBERs, who shall be persons under twenty-five years of age studying with a view to making navigation, or an allied interest, their ctreer.

(5) CORPORATE Members, who shall be companies, universities, navigation schools, government departments and other organizations, here and abroad, who are directly or indirectly interested in the science of navigation. Corporate Members are entitled to send representative to all Institute meetings and to receive six copies of the journal, and other publications. They are encouraged to take an active part in the Institute's work. Applications should be sent by letter addressed to the Director.

Subscriptions. Annual subscriptions to the Institute are payable in advance as follows:

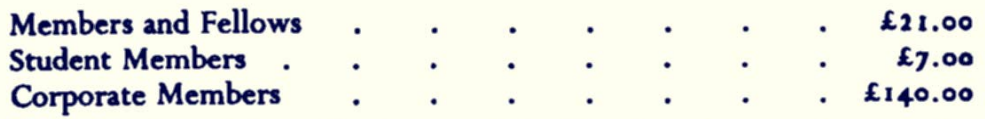

The Institute's financial year begins on I July. Members in any category who are elected after I January in any year are only due for one half of their subscription until 1 July, when the full subscription for the next year becomes due. 


\section{CAMBRIDGE UNIVERSITY PRESS}

The Pitt Building, Trumpington Street, Cambridge CB2 1 RP 32 East $57^{\text {th }}$ Street, New York, N.Y. 10022

Printed in Great Britain at the University Press Cambridge 